\title{
THE REGULATION OF THE SHADOW BANKING SYSTEM IN THE EUROPEAN UNION
}

\author{
O. Mitev* \\ Faculty of Economic and Social Sciences, Plovdiv University "Paisii Hilendarski”, Plovdiv, Bulgaria
}

\begin{abstract}
Introduction: The European Union is the second-largest market of shadow banking activities, which represent an important part in the post-crisis regulatory reform. Not subject to traditional banking regulation, characterized with specific advantages in terms of credit mediation and also specific risks such as systemic and risk of bank runs the shadow banking entities are an important part of the newly forged financial order. PURPOSE: To show the risks and advantages of shadow banking and to analyse some of the regulatory actions taken in the European Union concerning it. METHODS: Analysis of publications, policy and framework recommendations by regulatory bodies and organizations. Evaluation of said recommendations' ability to cope with shadow bank specific risks. CONCLUSIONS: Many of the risky activities once normal to traditional banks have since the postcrisis regulatory reform migrated to the less regulated shadow banking sector. As more funds seek higher profit in financial markets, the more important the issues in the shadow banking sector become. European authorities must seek a balance between regulation and deregulation so as not to push the same funds away, especially when Europe is facing a slow recovery. Issues in transparency, investor disclosure, reporting and data collection are central to a successful reform.
\end{abstract}

Key words: banking, regulatory changes, Europe

\section{INTRODUCTION}

After the onset of the financial crisis of 2007 , the focus of financial reform has been the regular banking system. However, it can be said that the regulation of non-bank financial institutions also plays a significant role in the post-crisis regulatory reform in the European Union.

The term "shadow banking" has been attributed to the economist Paul McCulley. For the purpose of this paper the definition used will be the one given by the Financial Stability Board in Strengthening Oversight and Regulation of Shadow Banking (1):"credit intermediation involving entities and activities (fully or partially) outside the regular banking system." Those activities are mainly credit intermediation and liquidity and maturity transformation.

Correspondence to: Ognyan Mitev, Faculty of Economic and Social Sciences, Plovdiv University "Paisii Hilendarski", Plovdiv, Bulgaria, 24 Tsar Assen Street, 4000 Plovdiv, tel 0878270277 , e-mail: ogimitev@gmail.com
The aim of this paper is to give a broad description of the risk and benefits of shadow banking and show some of the changes in financial regulation of shadow banking entities in the EU and their effect.

As we can see from the chart showing the ratio of other financial instructions and financial auxiliaries' size to banks' size in the Euro Area (Chart 1), the size of the shadow banking sector continues to grow, especially in terms of assets held by other financial intermediaries (OFIs) and financial auxiliaries relative to assets held by banks in the Euro area. Even though that using this ratio as a gauge for size is broad, this data confirms the importance the shadow banking system now plays in the European financial markets. Not only that, but this is an indication that the more regulated the regular banking sector becomes, the more investors are turning to the shadow banking system.

The European Commission in their Green paper on shadow banking (2) describe the shadow banking system as including: "First, entities operating outside the regular banking 
system engaged in one of the following activities:

- accepting funding with deposit-like characteristics;

- performing maturity and/or liquidity transformation;

- undergoing credit risk transfer; and,

- using direct or indirect financial leverage.

Second, activities that could act as important sources of funding of non-bank entities. These activities include securitisation, securities lending and repurchase transactions ("repo")" The financial regulatory reform in Europe had the goal of stabilizing the banking system by improving different areas of banking, such as: supervision by authorities, transparency, new mechanisms for restructuring.

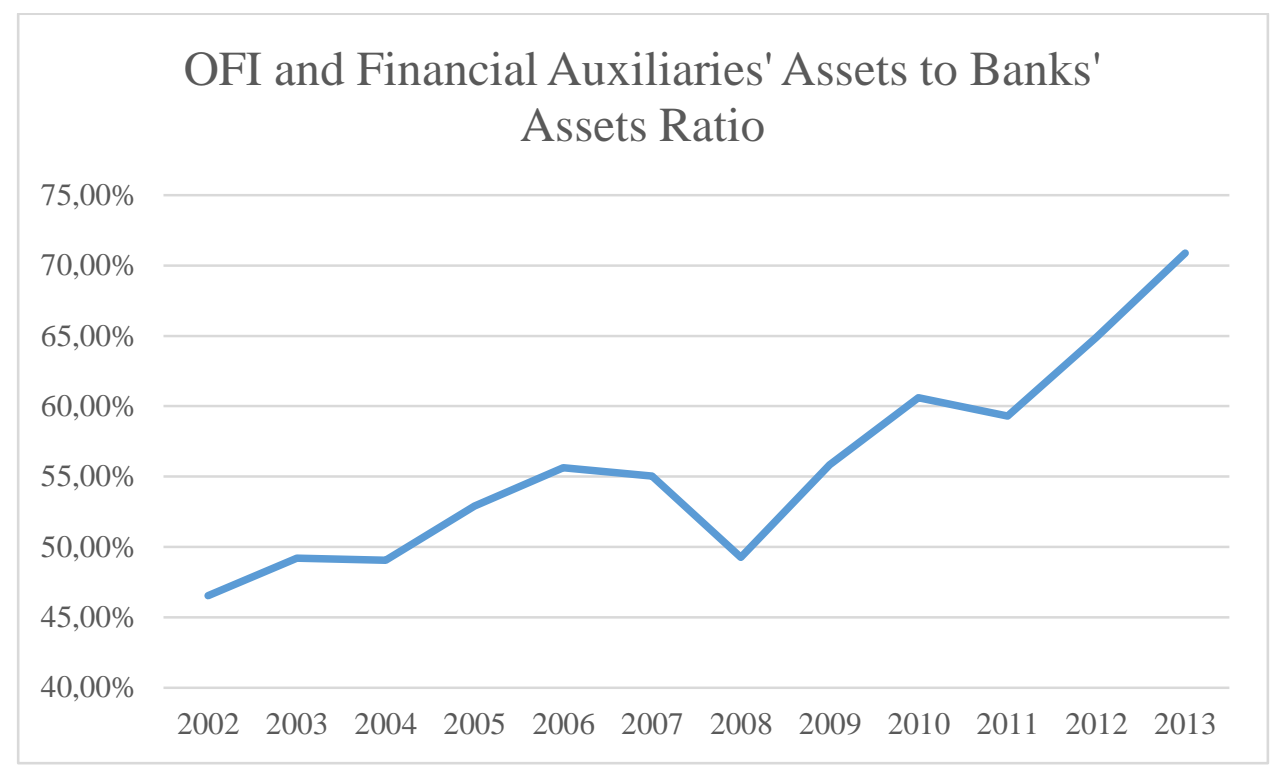

Chart 1. Ratio of Other financial instructions and financial auxiliaries' size to banks' size in terms of \$ trillions in the Euro Area. Source; Financial stability board

\section{ADVANTAGES OF SHADOW BANKING}

Shadow banking can provide additional funding and liquidity into financial markets. Those services are an alternative to deposits in regular banks. Credit expansion by the shadow banking entities was often welcomed by regulators who saw this as an opportunity to keep the markets liquid with little risk for insured banks. MMFs are key investors in commercial paper, providing additional financing to both financial institutions and non-financial companies that rely on shortterm debt for funding. (3)

Another benefit of the shadow banking system is the securities lending. It is an alternative source of capital and allows borrowers to purchase securities at below-market rates and in this way enhancing liquidity.

The mixture of securities, which are held by shadow banks, have different risk and maturity characteristics. The variety provides investors with choice and more freedom in diversifying their portfolios. Securitization in particular can promote greater portfolio diversification and efficient transfer of risk across products, borrowers and locations. This diversification also happens away from the regulated banking sector, enabling investors to benefit from multiple sources of funding.

Entities operating in the shadow banking system are numerous. Often they are specialized in a certain type of activity. This specialization and expertise along with their scale and scope makes them cost-efficient and they transfer this efficiency to their investors. Money-market mutual funds, for example, provide means to invest in products with slightly higher risk and reward profiles than traditional bank deposits while still being deemed relatively 'safe' because they provide short-term credit for companies

\section{RISKS OF SHADOW BANKING}

Some of the risks associated with shadow banking have systemic nature, because of the complexity of the activities in the system, their global scope and the mobility of traded securities. Moreover, the shadow banking and traditional banking sectors are interconnected. The benefits laid out above also have hidden costs. Engaging in liquidity and maturity transformation makes entities susceptible to bank runs. Short-term liabilities cannot be 
satisfied with the long-term illiquid assets on their balance sheets in the case of redemptions on a bigger scale. "In times of market turmoil, regular banks can address their asset-liability mismatch through access to central bank funding and government deposit insurance. Shadow banking actors have no such stabilizing backstops, making them heavily dependent on the constant provision of shortterm funds and, as a result, susceptible to runs".(3)

As noted by Adair Turner 'the system can for a period of time appear to promise combinations of lower risk, higher return, and greater liquidity that cannot objectively in the long term be sustained'. (4)

The shadow banking system and the traditional banking sector are interconnected. Not only that, but many commercial banks have divisions which operate separately in the shadow banking system. This explains the systemic risk inherent for this system. Under uncertain market conditions contagion may spread from and between the shadow banking and regulated banking sectors. Money-market funds are a source of funding for banks while also borrowing directly, or receiving implicit support, from those same banks.

Banks may also be compelled to provide support for the SPVs and other off-balancesheet entities they are perceived to have sponsored in times of market stress either for reputational reasons or because of funding commitments. Banks also regularly invest in products issued by shadow banking entities, such as the top tier tranches of securitized products issued by Structured Investment Vehicles, often referred to as 'super senior'. Fire sales by shadow banking entities can depress asset prices and weaken bank balance sheets.

Opportunities for regulatory arbitrage also occur when we are comparing two sectors with different levels of regulation. Commercial banks may use the more relaxed regulatory regime that shadow entities use and take on more risk to enhance their profit. Often they would use securitization to lower their capital requirements. Before the financial crisis, for example, mortgage loans bundled into a security would have been deemed less risky than a similar loan which was not. The vigorous regulatory reform after the financial crisis has served to worsen the problem of regulatory arbitrage, since now higher capital and liquidity requirements are in place. Use of off-balance-sheet operations, also helped banks to reduce the size of their balance sheets and to limit their mandatory capital requirements.

A very important moment is the buildup of leverage in the system. The abundance of cheap money created asset bubbles. When the buyers became fewer and with less purchasing power the bubbles stopped inflating and soon they burst. The loss in asset value spurred fire sales and margin calls. What matters even worse was the fact that organizations from both regulated banking sector and the shadow banking sector had invested in the same assets.

\section{REGULATION OF THE SHADOW BANKING SYSTEM}

The improving of regulation in the shadow banking system has been an important subject at several G20 summits. During the G20 summit in Cannes in November 2011 gave the task of designing policies which address the risks posed by the shadow banking system. The work done by the Financial Stability Board produced a set of policies which aimed to strengthen regulation and reduce systemic risk in certain areas. They are:

“ - mitigating risks in banks' interactions with shadow banking entities;

- reducing the susceptibility of money market funds (MMFs) to "runs";

- improving transparency and aligning incentives in securitisation;

- dampening pro-cyclicality and other financial stability risks in securities financing transactions such as repos and securities lending; and

- assessing and mitigating financial stability risks posed by other shadow banking entities and activities." (1)

\section{MITIGATING RISKS IN BANKS' INTERACTIONS WITH SHADOW BANKING ENTITIES}

The second product of the FSB's work is a monitoring framework, which finds systemic risk build-ups and enables corrective actions.

As the financial crisis of 2007 showed the financial markets are integrated and contagion can spread quickly. In order to address this issue, the Basel Committee on Banking Supervision has taken steps to building a policy which reduces the risks of spillover of negative events from the shadow banking system to the regular banking system. The channel which can carry those negative effects can be two. The first one is the credit regular banks offer to shadow, non-bank entities, such as credit enhancements and liquidity lines). The second one is a potential fire sale of assets by shadow banks when liquidity worries occur. The sale of those assets can deflate the balance 
sheets of any institution holding those assets regardless of whether or not they have backstops in place.

The Basel Committee has developed a policy which improves the international consistency of the scope of consolidation for prudential regulatory purposes. The purpose is to enable supervisors to capture all banks' activities within the regulatory regime. This limits the regulatory arbitrage opportunities.

Another area where the Basel Committee has taken steps to improving supervision is measuring and controlling large exposures. The proposals seek to protect banks from the risk of the default of single private sector counterparties, including entities involved in shadow banking. Banks would be required to scan through their exposures and finds those attributed to a single counterparty. That includes: shadow banking entities, funds and securitisation structures. It is not a surprise that this practice would help track large exposures on a balance sheet. This is another step in containing the spillover risk to banks which deal with entities from the shadow banking system.

\section{REDUCING THE SUSCEPTIBILITY OF MONEY MARKET FUNDS (MMFS) TO BANK RUNS}

Commercial banks share the same risks as shadow bank entities. The difference is that the latter do not face the constraints, regarding regulation and supervision, which are imposed on the former. Shadow banks have characteristics similar to depositary institutions. They use short-term financing to fund long-term projects. This means that they engage in maturity and liquidity transformation. Money market funds provide a deposit-like instrument to investors, especially when they are redeemable on short notice and at par. This makes the susceptible to bank runs. A bank run is a situation where individuals and organizations, which have invested with the bank, decide to withdraw their deposits in large quantities and in a very short period of time. This creates a liquidity problem for the institution which suffers the run. The obligations to the depositors must be met and entities may result to assistance form other banks or the central bank. Institutions, operating in the shadow banking system, such as money market funds, cannot rely on such assistance. To meet their obligations they are forced to sell assets, which lowers the price of those assets across the board and the balance sheets of other institutions which are not suffering a bank run, will also suffer. Through their placement of investor funds, MMFs extend credit, and are also an important provider of short-term funding for the regular banking system as well as for other non-bank chains of credit intermediation that involve maturity transformation and leverage.

During the financial crisis a large portion of money market funds were the victims of contagion caused by investor runs.

The organization which took on the task of preparing policy recommendations for the regulation of money-market funds is the International Organization of Securities Commissions (IOSCO). The Financial Stability Board has backed up the recommendation by IOSCO that moneymarket funds which offer a stable or constant net asset value (NAV) should be converted into floating NAV where possible. (5)

Where such conversion is not workable, the FSB believes that the safeguards required to be introduced to reinforce stable NAV MMFs' resilience to runs should be functionally equivalent to the capital, liquidity, and other prudential requirements on banks that protect against runs on their deposits. (6)

Another European organization which published recommendations on the same topic is the European Systemic Risk Board. Their recommendations include: mandatory conversion of stable NAV MMFs to floating NAV MMFs in order to reduce the shareholders' incentive to run when the MMF has experienced a loss; additional liquidity requirements; additional public disclosure on important features; and more detailed reporting by MMFs. (7)

\section{IMPROVING TRANSPARENCY AND ALIGNING INCENTIVES IN SECURITISATION}

Going back to the financial crisis of 2007 it is impossible to underestimate the importance of the lack of transparency in the dealings of banks. Investment banks and insurance companies were involved in large scale bundling, packaging and repackaging of different instruments, thinking that risk will be nearly eliminated. In fact, what was created was a complex web of financial instruments which made it difficult to assess the situation in the run up to the crisis. Misaligned incentives were normal and what followed was a build-up of leverage and maturity mismatches. A number of regulatory reforms have since been introduced to address the information asymmetries and incentive 
problems associated with these forms of securitisation.

IOSCO issued a report in November 2012 that took stock of the implementation of reforms,

especially those related to retention requirements, and measures that enhance transparency and standardization of securitisation products. The goal is an alignment of incentives regarding risk retention requirements. IOSCO has since conducted a peer review to assess the efficacy of those approaches in its member jurisdictions. (8)

\section{SECURITIES FINANCING TRANSACTIONS}

A very important issue in securities financing transactions is their use by shadow bank entities. They carry risks from maturity and liquidity transformation. During the financial crisis the collateral behind those transactions depreciated, spurring fire sales of assets which worsened the crisis. Such securities financing transactions are the repurchase agreement and securities lending. They are essential to financial intermediaries' market-making activities as well as to their various investment and risk management strategies. The organization which created policy recommendations for this issue was the Financial Stability Board. Their aim was to reduce the shadow banking system's dependence on this form of short-term wholesale funding. Measures to reduce excessive leverage were also. The amount of financing which can be provided against a security is being revised. Also a framework of minimal margins was proposed to prevent the erosion of margins when shadow bank institutions "leverage through the use of securities financing transactions backed by non-government securities" (9)

\section{REGULATION IN THE EU. INDIRECT STEPS.}

The issues concerning the shadow banking system in the European Union were addressed both directly and indirectly. Those steps have been pointed out in the EU Commission's Green paper on shadow banking from 2012. The first indirect step, and probably the most important one, was the revision of the capital requirements in the EU in 2009. The changes made regulations in the EU to comply with the Basel II and Basel II Accords, with the latest capital requirements directive put into force in the summer of 2013. The idea is that underwriters of security retain much of the risk, so as to diminish moral hazard.
The directive also reinforced the treatment of liquidity lines and credit exposure to securitization vehicles. The previous rules had allowed banks to avoid posting capital for the corresponding risks.

Capital Requirements Directive 3 required competent authorities in all Member States, when carrying out their risk assessment of individual banks under Pillar 2 of the Basel/CRD framework, to take into account reputational risks arising from complex securitisation structures or products. Not only that, but banks have to comply with new disclosure rules and hold more capital, the more complex the resecuritisation is. (2)

One of the more direct measures adopted in the EU concerning shadow banking, is Alternative Investment Fund Managers Directive (AIFMD) (10). The institutions that fall under that directive have to be alternative investment funds. The managers in those funds should "monitor liquidity risks and employ a liquidity management system". In addition new requirements on reporting are in place, as well as new methods for calculating leverage. This makes monitoring repurchase agreements deals and securities lending easier.

Credit rating agencies had a significant role to play in the financial crisis of 2008. Subsequent investigation showed conflict of interest in their management and practices which may have mislead investors. Assigning ratings to financial products and entities, gives them indirect, but important, influence over investment decisions. They are now subject to more stringent regulation and supervision. (11) The last moment in direct regulation covered here will be the vigorous risk management requirements set in place with Solvency II. The goal is to address the potential negative effects of unaddressed shadow banking issues in insurance. To be more specific the new risk management requirements include a "prudent person" principle for investments. "explicitly covers credit risks in capital requirements; provides for a total balance sheet approach where all entities and exposures are subject to group supervision; and, is as stringent in respect of credit risk as CRD IV" (2)

\section{CONCLUSION}

Many of the efforts in the regulation of the shadow banking system have the regulatory reforms in capital requirements for regular banks and financial intermediaries as orientation. The degree of financial regulation which has passed in the shadow banking system depends to a great extent on the 
MITEV O.

aftermath of the financial crisis. Had that aftermath been more prolonged and caused greater damage, the regulations would have been much stricter. As a whole the shadow banking system, has been out of the spotlight during the regulatory process, with the focus put on commercial banks. The entities comprising the shadow banking system are diverse and they have different activities. Over regulation in that sector would be an unwelcome decision. Risk appetite must remain if investors are to seek profitability, which now they cannot find in the regular banking sector. It becomes clear that shadow banking will be an important factor when considering the overall stability of the financial system in the European Union. The organizations have certain advantages and specialization which will serve a role in restoring confidence in the future of financial markets. The financial system in Europe is becoming more and more complex. In order to address those issues it is important to target economic activities rather than organizations themselves for regulation. The Financial Stability Board is a good example for that, targeting functions which create risk for the financial system. At the same time it is important that the shadow banking system remains different from the traditional banking sector. Riskier investments need to be able to develop, with the proper supervision and regulation, of course. Improving transparency and investor information, a more efficient gathering and use of data from non-banking entities to measure risk are key factors in this endeavor. Risky activities migrated from the traditional banking sector because of tightening regulation. If the same happens with the shadow banking sector, then those activities will migrate somewhere else, always avoiding regulation. That is why the efforts of regulators and national supervisors should be aimed at achieving a well-balanced shadow banking system, where the characteristic advantages of the institutions in it are used to spur economic growth which the European Union needs.

\section{REFERENCES}

1. Financial Stability Board, Shadow Banking: Strengthening Oversight and Regulation:Recommendations of the Financial Stability Board, 2011, http://www.financialstabilityboard.org/wpcontent/uploads/r_111027a.pdf, Accessed on May 22, 2015

2. European Commision, Green paper on shadow banking, 2012, http://ec.europa.eu/internal_market/bank/docs /shadow/green-paper_en.pdf, Accessed on May 20, 2015

3. Edward F. Greene and Elizabeth L. Broomfield, Promoting risk mitigation, not migration: a comparative analysis of shadow banking reforms by the FSB, USA and EU, 2012,

http://cmlj.oxfordjournals.org/content/8/1/6.fu 11.pdf?keytype=ref\&ijkey=KwUYMqxetigDf uq, Accessed on May 28, 2015

4. Speech by Lord Turner, FSA Chairman at the Cass Business School, (March 2012) http://www.fsa.gov.uk/static/pubs/speeches/0 314-at.pdf, Accessed on May 21, 2015

5. International Organization of Securities Commissions (IOSCO), POLICY RECOMMENDATIONS

FORMONEYMARKET FUNDS, 2012. http://www.iosco.org/library/pubdocs/pdf/IOS COPD392.pdf, Accessed on May 28, 2015

6. Financial Stability Board, Strengthening Oversight and Regulation of Shadow Banking An Integrated Overview of Policy Recommendations, 2012, http://www.financialstabilityboard.org/wpcontent/uploads/r_121118.pdf, Accessed on June 2, 2015

7. European Systemic Risk Board, RECOMMENDATION OF THE EUROPEAN SYSTEMIC RISK BOARD, 2012,

http://www.esrb.europa.eu/pub/pdf/recommen dations/2012/ESRB_2012_1.en.pdf?4e30873f 97c21330632e252d505927c8, Accessed on 20 May 2015

8. International Organization of Securities Commissions (IOSCO), Global Development in Securitisation Regulation, 2012, http://www.iosco.org/library/pubdocs/pdf/IOS COPD394.pdf, Accessed on June 5,2015

9. Financial Stability Board, Strengthening Oversight and Regulation of Shadow Banking A Policy Framework for Addressing Shadow Banking, 2012, http://www.financialstabilityboard.org/wpcontent/uploads/r_121118b.pdf, Accessed on June 2, 2015

10. Directive 2011/61/EC of the European Parliament and of the Council of 8 June 2011 on Alternative Investment Fund Managers and amending Directives 2003/41/EC and 2009/65/EC and Regulations (EC) No 1060/2009 and (EU) No 1095/2010, OJ L 174, 1.7.2011, p.1.

11. Proposal for a Regulation of the European Parliament and of the Council amending Regulation (EC) No 1060/2009 on credit rating agencies, $\operatorname{COM}(2011) 747$ final of 15.11.2011. 